\title{
Письмо редактора
}

Уже становится традицией, что летний номер журнала «Интеракция. Интервью. Интерпретация» фокусируется на городской тематике. В данном номере представлена теоретическая работа о концепции аутентичности, статьи, написанные по итогам полевых исследований в двух российских городах, а также рефлексивные заметки по поводу геолокационных данных. Читатель июньского номера узнает, какой ритуал лежит в основе Дня амурского тигра во Владивостоке и что с этим ритуалом происходит в настоящее время, о чем помнит малый город в Вологодской области, нужен ли городским исследователям еще один метафорический концепт и как использовать возможности геолокационных данных.

В текущем номере также представлена подробная рецензия на актуальную книгу Венди Боттеро «Чувство неравенства» ("А Sense of Inequality", 2019). Автор рецензии, Елизавета Полухина, рассуждает о применимости эмоционально-ориентированного подхода к концептуализации социального неравенства. Елизавета соглашается с В. Боттеро в том, что субъективное неравенство можно трактовать как специфическое чувство индивидов, возникающее во множестве повседневных неравноправных социальных отношений. Эта трактовка и стоящий за ней набор идей применимы к широкому спектру городских исследований.

В заключение отмечу, что есть исследователи, которые с азартом погружаются в поле, но практически не оставляют времени на тексты по итогам своих проектов. И вот этой весной, кажется, для всех время перераспределилось в пользу кабинетной работы. Во всяком случае, один из авторов номера, Виктор Синицын, за время полевой «паузы» доработал давно написанную статью по итогам экспедиции в г. Белозерск. Из его статьи читатели узнают о том, как формируется и из чего состоит мемориальный ландшафт малого города. Надеемся, что многим нашим авторам и читателям период самоизоляции и вынужденное превращение в кабинетных ученых также помогли превратить массивы полевых данных в интереснейшие публикации.

Желаем приятного и продуктивного чтения!

А. Стрельникова, ответственный редактор номера 